Article

\title{
Biological Activity of Volatiles from Marine and Terrestrial Bacteria
}

\author{
Stefan Schulz ${ }^{1, \star}$, Jeroen S. Dickschat ${ }^{1}$, Brigitte Kunze ${ }^{2}$, Irene Wagner-Dobler ${ }^{2}$, Randi Diestel ${ }^{3}$ \\ and Florenz Sasse ${ }^{3}$ \\ ${ }^{1}$ Institute of Organic Chemistry, University of Braunschweig-Institute of Technology, Hagenring 30, \\ 38106 Braunschweig, Germany; E-Mail: j.dickschat@tu-bs.de (J.S.D.) \\ ${ }^{2}$ Research Group Microbial Communication, Helmholtz Center for Infection Research, Inhoffenstrasse \\ 7, 38124 Braunschweig, Germany; E-Mails: brigitte.kunze@helmholtz-hzi.de (B.K.); \\ irene.wagner-doebler@helmholtz-hzi.de (I.W.-D.) \\ ${ }^{3}$ Department of Chemical Biology, Helmholtz Center for Infection Research, Inhoffenstrasse 7, 38124 \\ Braunschweig, Germany; E-Mails: randi.diestel@helmholtz-hzi.de (R.D.); \\ florenz.sasse@helmholtz-hzi.de (F.S.)
}

* Author to whom correspondence should be addressed; E-Mail: Stefan.Schulz@ tu-bs.de; Tel.: +49-531-391-7353; Fax: +49-531-391-5272.

Received: 12 November 2010; in revised form: 7 December 2010 / Accepted: 17 December 2010 / Published: 22 December 2010

\begin{abstract}
The antiproliferative activity of 52 volatile compounds released from bacteria was investigated in agar diffusion assays against medically important microorganisms and mouse fibroblasts. Furthermore, the activity of these compounds to interfere with the quorum-sensing-systems was tested with two different reporter strains. While some of the compounds specific to certain bacteria showed some activity in the antiproliferative assay, the compounds common to many bacteria were mostly inactive. In contrast, some of these compounds were active in the quorum-sensing-tests. $\gamma$-Lactones showed a broad reactivity, while pyrazines seem to have only low intrinsic activity. A general discussion on the ecological importance of these findings is given.
\end{abstract}

Keywords: lactones; sulfur compounds; pyrazines; bacterial communication; quorum-sensing; ketones; aromatic compounds; agar diffusion assay; terpenes 


\section{Introduction}

Marine bacteria are a rich source of natural products with interesting biological and pharmacological activities [1,2]. While most research on marine bacterial metabolites focusses on compounds with moderate polarity isolable from fermentation experiments, relatively few volatile compounds from marine as well as other bacteria are known [3]. Many bacteria, marine or terrestrial, produce volatiles, but the specific function of these compounds is known only in few cases. It seems likely that the volatiles are used either in intra- or inter-specific communication and/or in the chemical defence against other microorganisms. Several studies have shown that bacterial volatiles can indeed influence the growth of other organisms [4]. Bacterial volatiles can impact, most often inhibit, the growth of fungi [4-9], but only few studies describe the activities of certain compounds. Compounds identified from fungistatic soil bacteria inhibiting spore germination of certain fungi were acetamide, trimethylamine, 3-methyl-2-pentanone, benzaldehyde, $N, N$-dimethyloctylamine, benzothiazole, 1-butanamine, methanamine, phenylacetaldehyde, and 1-decene [10,11]. Benzothiazole, cyclohexanol, nonanal, decanal, dimethyl trisulfide, and 2-ethyl-1-hexanol, the latter most likely an anthropogenic artefact, identified from several Pseudomonas strains, were active in inhibiting growth of the plant pathogen, Sclerotinia sclerotiorum [12]. 1-Undecene and dimethyl disulfide (2), released by several bacteria, were also active [4], despite the fact that the latter proved to be inactive in other studies [10-12]. Effects on plants have been described for 2,3-butanediol (47) and acetoin (48) which improve plant growth in Arabidopsis thaliana, and also effects on animals have been described [4]. On the other hand, reports on interbacterial effects of volatile compounds are rare. Indole acts as a signalling compound in Escherichia coli [13] and shows effects on other bacteria [14] while volatile carboxylic acids inhibit spore formation in several pathogenic bacteria [15].

More or less all studies performed so far concentrated on the evaluation of the effects of readily available compounds. While these studies showed activity in some cases, questions remain about the activity potential of other components. The volatiles identified so far can be roughly divided into different groups depending on their occurrence. While there are common compounds produced by many different, often unrelated bacteria, e.g., dimethyl disulfide (52), or at least by certain groups as geosmin (49) and 2-methylisoborneol (50) found in actinobacteria, myxobacteria, and cyanobacteria, some are unique for certain strains as the lactones 4-11 [3].

In the present study 52 compounds were tested for their biological effects, covering strain or species specific compounds (1-44) and commonly occurring ones (45-52). In a first set of experiments we established a general profile of the biological activities of these compounds. Therefore, the antiproliferative activity with bacteria, fungi, and murine fibroblasts was tested. The antimicrobial assays were focussed on medically important strains. In a second set of experiments the possibility of interference with well known bacterial chemical communication channels was probed. In this context, the compounds were investigated in an assay on bacterial crosstalk [16] to demonstrate whether they can influence the known bacterial quorum-sensing signalling pathway via $N$-acylhomoserine lactones (AHLs).

The compounds tested (Figure 1) were identified from different marine bacteria (see Table 1 for references). Several compounds originally known from terrestrial bacteria are also included to compare 
activities between compounds originating from terrestrial or marine sources. Nevertheless, there is no clear cut difference in chemistry between terrestrial and bacterial microorganisms. Common compounds usually occur in both areas.

Figure 1. Compounds used in this study. Acids, alcohols, lactones, ketones, amides, pyrazines, sulfur compounds, aromatic compounds, and substances commonly occurring as bacterial volatiles (45-52).<smiles>CCCCCCCC(=O)O</smiles><smiles>CC(C)CCCCCC1CCC(=O)O1</smiles>

4<smiles>CCC(C)CCCCCC1CCC(=O)O1</smiles>

7<smiles>CCC(O)CCCCCC(C)C</smiles><smiles>CC(C)CCCCCC1C=CC(=O)O1</smiles>

5<smiles>CC(C)CCCCCCCC(C)O</smiles>

3<smiles>CC(C)CCCCCC1=CCC(=O)O1</smiles>

6<smiles>CC(C)CCCCC1CCCC(=O)O1</smiles><smiles>CCC(=O)CCCCCC(C)CC</smiles>

11

12<smiles>CCCCCCCCCC(=O)C(C)CC</smiles>

15<smiles>CCCCCCCCC(=O)C=C(C)C</smiles><smiles>CCCCCCCCCC(=O)CC(C)C</smiles><smiles>CC(=O)CCCCC/C=C/CCCC(C)C</smiles>

18<smiles>CC(=O)CCCCCCCCC/C=C/CC(C)C</smiles>

19<smiles>CC(C)CCNC=O</smiles>

20<smiles>CC(C)CCC(=O)NCCc1ccccc1</smiles>

23<smiles>CCCCc1nc(C)cnc1C</smiles><smiles>CC(=O)NCCC(C)C</smiles>

21<smiles>CCC(C)CC(=O)NCCc1ccccc1</smiles>

22<smiles>O=C(NCCc1ccccc1)c1ccccc1</smiles>

24<smiles>C=C(C)c1cnc(C(C)C)cn1</smiles>

27<smiles>CC(C)Cc1cnc(CC(C)C)cn1</smiles>

25<smiles>COc1nc(C)cnc1C</smiles>

28 
Figure 1. Cont.<smiles>COc1ncc(CC(C)C)nc1CC(C)C</smiles>

29<smiles>COc1nc(CC(C)C)cnc1CC(C)C</smiles>

30<smiles>CCC(C)c1cnc(C(C)CC)c(OC)n1</smiles>

31<smiles>CSc1nc(C)cnc1C</smiles>

32<smiles>CSCCC(C)O</smiles>

33<smiles>CSCCC(=O)SC</smiles>

34<smiles>CSC(=O)c1ccccc1</smiles>

35<smiles>CCc1ccc(CC(C)C)s1</smiles>

36<smiles>CC1(C)CSSC(C)(C)CS1</smiles>

37

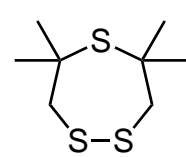

38<smiles>CC1(C)CSSCC(C)(C)SS1</smiles>

39<smiles>CC1(C)CSSC(C)(C)CSS1</smiles>

40<smiles>CCCCCc1ccccn1</smiles>

41<smiles>CC(C)CC(=O)OCc1ccco1</smiles>

42<smiles>OCc1ccco1</smiles>

43<smiles>O=c1cccccc1</smiles>

44<smiles>CC(C)CCO</smiles>

45<smiles>OCCc1ccccc1</smiles>

46<smiles>C[C@H](O)[C@@H](C)O</smiles>

47<smiles>CC(=O)C(C)O</smiles>

48<smiles>C[C@@H]1CCC[C@@]2(C)CCCC[C@]12O</smiles>

49



50



51<smiles>CSSC</smiles>

52

\section{Results and Discussion}

Classical agar diffusion assays were performed using the fungi Aspergillus fumigatus, Botrytis cinerea, and Pythium debaryanum as well as the yeasts Hansenula anomala, Saccharomyces cerevisiae, and Candida albicans. Furthermore, the bacteria Pseudomonas aeruginosa, Klebsellia pneumoniae, Staphylococcus aureus, Micrococcus luteus, Mycobacterium phlei and a mutant of Escherichia coli which is defective in the tolC gene [17] were used as test organisms. The results are shown in Table 1. Octanoic acid (1) is active against hyphal fungi and yeasts, as are the amides $\mathbf{2 2}$ and 23. $\gamma$-Butyrolactones 4-8 are active against fungi, yeasts, and bacteria, with a large influence of a double bond in the ring. Expansion of the ring to $\delta$ - (9) or $\epsilon$-lactones (10 and $\mathbf{1 1})$ reduces the activity. 9-Methyl-3-decanol (2), the characteristic component of the headspace volatiles of Myxococcus xanthus, shows activity against Gram-positive bacteria and the tolC mutant of Escherichia coli, while alcohol 3 only inhibits the sensitive E. coli mutant. Pyrazines (25-32) as well as ketones (12-19) are largely inactive with the exception of (Z)-15-methylhexadec-12-en-2-one (19), showing broad activity. $S$-Methyl benzothioate (35) is the only sulfur containing compound with activity against fungi and yeast, while all others (32-40) are inactive. 2-Pentylpyridine (41), produced by a Streptomyces strain [18], is slightly active against $S$. cerevisiae, E. coli, and $K$. pneumoniae. In contrast, the latter bacterium and C. albicans are the only microorganisms furfuryl isovalerate (42) is not active against. 
The results discussed so far were obtained with compounds produced only by specific bacterial strains. In contrast, the compounds common to many bacteria showed no inhibitory activity. This is even true for components as dimethyl disulfide (52) which showed activity in other assays [4].

Table 1. Agar diffusion inhibition assay. Asf: Aspergillus fumigatus; Boc: Botrytis cinerea; Caa: Candida albicans; Pyd: Pythium debaryanum; Hna: Hansenula anomala; Scc: Saccharomyces cerevisiae; tolC: E. coli tolC mutant; Psa: Pseudomonas aeruginosa; Kbp: Klebsellia pneumoniae; Sta: Staphylococcus aureus; Mcl: Micrococcus luteus; Myp: Mycobacterium phlei; Amount: amount of compound used in the agar diffusion assay; $\mathrm{mm}$ : diameter of inhibition zone; i: incomplete inhibition; MIC: cytotoxic activity against L-929 mouse fibroblasts, minimal inhibition concentration; Oc: source.

\begin{tabular}{|c|c|c|c|c|c|c|c|c|c|c|c|c|c|c|}
\hline \multirow{2}{*}{\multicolumn{2}{|c|}{ No Compound }} & \multirow{2}{*}{\multicolumn{2}{|c|}{$\begin{array}{l}\text { Amount } \mathrm{A} \\
\mu \mathrm{g} \quad \mathrm{n}\end{array}$}} & \multicolumn{3}{|c|}{ Boc Pyd Caa Hna Scc t } & \multirow{2}{*}{\multicolumn{2}{|c|}{$\begin{array}{l}\text { tolC Psa } \\
\mathrm{mm} \quad \mathrm{mm}\end{array}$}} & \multirow{2}{*}{\multicolumn{2}{|c|}{ Kbp Sta }} & \multicolumn{3}{|c|}{ Mcl MypMIC } & \multirow[t]{2}{*}{ Oc } \\
\hline & & & & & & & & & & $\mathrm{mm} \mathrm{r}$ & & & & \\
\hline 1 & Octanoic acid & 112 & $10 \mathrm{i}$ & & $11 \mathrm{i}$ & $11 \mathrm{i}$ & & 0 & 0 & $0 \quad($ & 0 & 0 & 480 & (1) \\
\hline 2 & 9-Methyl-3-decanol & 156 & 0 & 0 & 0 & 0 & 12 & 0 & $0 \varepsilon$ & 81 & 13 & 20 & 560 & [19] \\
\hline 3 & 10-Methylundecan-2-ol & 382 & 0 & 0 & 0 & 0 & 8 & 0 & 0 & $0 \quad 0$ & 0 & 0 & 420 & [20] \\
\hline 4 & 10-Methylundecan-4-olide & 416 & 11 & 14 & 0 & 0 & 14 & 0 & 0 & $8 \mathrm{i}$ & $10 \mathrm{i}$ & 19 & 430 & [21] \\
\hline 5 & 10-Methylundec-2-en-4-olide & 346 & 15 & 14 & $9 \mathrm{i}$ & 14 & 17 & $11 \mathrm{i}$ & 0 & 98 & $8 \mathrm{i}$ & 11 & 363 & [21] \\
\hline 6 & 10-Methylundec-3-en-4-olide & 218 & $9 \mathrm{i}$ & 9 & 0 & 10 & 13 & $13 \mathrm{i}$ & 0 & $8 \mathrm{i} \&$ & $8 \mathrm{i}$ & 12 & 230 & [21] \\
\hline 7 & 10-Methyldodecan-4-olide & 428 & $8 \mathrm{i}$ & $10 \mathrm{i}$ & 0 & 0 & 15 & $12 \mathrm{i}$ & 0 & $8 \mathrm{i} \&$ & $8 \mathrm{i}$ & 13 & 415 & [21] \\
\hline 8 & 10-Methyldodec-2-en-4-olide & 140 & $8 \mathrm{i}$ & 8 & 0 & 9 & 20 & 0 & 0 &  & 8 & 10 & 135 & [21] \\
\hline 9 & 10-Methylundecan-5-olide & 250 & 0 & 0 & 0 & 0 & 0 & 0 & 0 & $0 \quad($ & 0 & 0 & 780 & [21] \\
\hline & 9-Methylundecan-6-olide & 28 & 0 & 0 & 0 & 0 & $8 \mathrm{i}$ & 0 & 0 & $0 \quad($ & 0 & $18 \mathrm{i}$ & 260 & [22] \\
\hline & 10-Methylundecan-6-olide & 30 & 0 & 0 & 0 & 0 & 0 & 0 & 0 & $0 \quad 0$ & 0 & 0 & 280 & [22] \\
\hline & 6-Ethyl-3-octanone & 304 & 0 & 0 & 0 & 0 & 0 & 0 & 0 & $0 \quad($ & 0 & 0 & $>1000$ & $(2)$ \\
\hline & 9-Methyl-3-decanone & 162 & 0 & 0 & 0 & 0 & 9 & 0 & 0 & $0 \quad($ & 0 & 0 & 590 & [19] \\
\hline & 9-Methyl-1-phenyldecan-1-one & 200 & 0 & $0 \quad 0$ & 0 & 0 & 0 & 0 & 0 & $0 \quad($ & 0 & 0 & 500 & [20] \\
\hline & 3-Methyltridecan-4-one & 528 & 0 & 0 & 0 & 0 & 0 & 0 & 0 & $0 \quad($ & 0 & 0 & 510 & [20] \\
\hline & 2-Methyltridec-2-en-4-one & 414 & 0 & 0 & 0 & $8 \mathrm{i}$ & 0 & 0 & 0 & $0 \quad($ & 0 & 0 & 405 & [20] \\
\hline & 2-Methyl-4-tetradecanone & 488 & 0 & 0 & 0 & 0 & 0 & 0 & 0 & $0 \quad($ & 0 & 0 & 443 & [20] \\
\hline & (Z)-13-Methyltetradec-8-en-2-one & 280 & 0 & 0 & 0 & 0 & 0 & 0 & 0 & $0 \quad($ & 0 & 0 & 257 & [23] \\
\hline & (Z)-15-Methylhexadec-12-en-2-one & 280 & $8 \mathrm{i}$ & $9 \mathrm{i}$ & 0 & 9 & 9 & $12 \mathrm{i}$ & 0 & $13 \mathrm{i}$ & 10 & 13 & 73 & [23] \\
\hline & Isopentyl formamide & 524 & 0 & 0 & 0 & 0 & 0 & 0 & 0 & $0 \quad($ & 0 & 0 & $>1000$ & [20] \\
\hline 21 & Isopentyl acetamide & 386 & 0 & 0 & 0 & 0 & 0 & 0 & 0 & $0 \quad($ & 0 & 0 & $>1000$ & [20] \\
\hline 22 & 3-Methyl- $N$-(2-phenylethyl)pentanamide & 290 & $12 \mathrm{i}$ & i $13 i$ & $15 \mathrm{i}$ & 0 & 11 & 0 & 0 & $0 \quad($ & 0 & 0 & 815 & [24] \\
\hline 23 & 4-Methyl- $N$-(2-phenylethyl)pentanamide & 130 & $10 \mathrm{i}$ & i 0 & $10 \mathrm{i}$ & 0 & $10 \mathrm{i}$ & 0 & 0 & $0 \quad($ & 0 & 0 & 365 & [24] \\
\hline 24 & $N$-(2-phenylethyl)benzamide & 282 & 0 & 0 & 0 & 0 & 0 & 0 & 0 & $0 \quad($ & 0 & 0 & 773 & [24] \\
\hline 25 & 2,5-Diisobutylpyrazine & 1322 & 0 & 0 & 0 & 0 & 20 & 0 & 0 & $0 \quad($ & 0 & 0 & $>1000$ & [25] \\
\hline 26 & 2-Butyl-3,6-dimethylpyrazine & 644 & 0 & 0 & 0 & 0 & 10 & 0 & 0 & $0 \quad($ & 0 & 0 & $>1000$ & [23] \\
\hline 27 & 2-Isopropenyl-5-isopropylpyrazine & 178 & 0 & 0 & 0 & 0 & 0 & 0 & 0 & $0 \quad($ & 0 & 0 & 680 & [26] \\
\hline 28 & 2-Methoxy-3,6-dimethylpyrazine & 217 & 0 & 0 & 0 & 0 & 0 & 0 & 0 & $0 \quad($ & 0 & 0 & 320 & [26] \\
\hline 29 & 2-Methoxy-3,5-diisobutylpyrazine & 354 & 0 & 0 & 0 & 0 & 10 & 0 & 0 & $0 \quad($ & 0 & 0 & $>1000$ & [26] \\
\hline 30 & 2-Methoxy-3,6-diisobutylpyrazine & 354 & 0 & 0 & 0 & 0 & 9 & 0 & 0 & $0 \quad 0$ & 0 & 0 & 327 & [26] \\
\hline
\end{tabular}


Table 1. Cont.



Additionally, the cytotoxic activity against L-929 mouse fibroblasts was investigated in concentration dependant assays. The obtained minimal inhibition concentration (MIC) values indicated moderate or no activity. The most active compounds were furfuryl isovalerate (42, MIC $62 \mu \mathrm{mol} / \mathrm{L})$, the ketone 19 (MIC $73 \mu \mathrm{mol} / \mathrm{L}$ ), the lactones 10 and 11 (MIC 260 and $280 \mu \mathrm{mol} / \mathrm{L}$ ), as well as the pyrazine 28 (MIC $320 \mu \mathrm{mol} / \mathrm{L}$ ). All these compounds were also active in at least some antimicrobial assays except 28.

All compounds were also investigated for their activity in $N$-acylhomoserine lactone (AHL) mediated bacterial communication systems (quorum-sensing). These test were performed using green fluorescent protein (gfp) equipped reporter strains capable of sensing AHLs with certain side chain specificity. The used E. coli MT102 (pJBA132) reporter shows the highest sensitivity for $N$-(3-oxohexanoyl)homoserine lactone (3-oxo-C6-AHL) [32], while the Pseudomonas putida F117 (pKR-C12) reporter is very sensitive to $N$-(dodecanoyl)homoserine lactone (C12-AHL) [33]. The corresponding AHLs were added to the sensor strains together with the test compound and the resulting reduction or increase of fluorescence was recorded (Table 2). Values of more than $50 \%$ were considered significant.

Several compounds were able to modify the sensor response. The lactones 5-9 inhibited the response of the C12-AHL sensor. Especially the $\delta$-lactone 9 was highly active. In contrast, the 3-oxo-C6-AHL sensor showed a different behavior. In particular 4 and $\mathbf{7}$ stimulated this sensor. This influence may be due to the structural similarity between the lactones and the AHLs. Ketones also proved to be active, 
with 15, 16, 18, 19, and the related alcohol 3 reducing activity of the C12-AHL sensor, while 17 did so with the 3-oxo-C6-AHL sensor, as did the pyridine derivative 41. The sulfur containing ester 34 and furfuryl isovalerate (42), also one of the most active compounds in the antimicrobial assays, were the only compounds able to reduce the activity of both sensors. In this assay also compounds common to many different bacteria showed some activity, reducing the effectivity of the 3-oxo-C6-AHL sensor. These compounds were the alcohols 45 and 46, and both enantiomers of methylisoborneol (50 and 51). In summary, $25 \%$ of the compounds were able to reduce activity of the C12-AHL sensor, while $19 \%$ show inhibitory activity against 3-oxo-C6-AHL and 13\% enhanced its activity.

Table 2. Acylhomoserine lactone assay using N-3-oxohexanoylhomoserine lactone for E. coli MT102 ( $\mathrm{C}_{6}$-AHL) and $N$-dodecanoylhomoserine lactone for $P$. putida $\mathrm{F} 117$ $\left(\mathrm{C}_{12}\right.$-AHL). The maximum reduction relative to the native ligand is reported $(\%)$. Negative values indicate no inhibition, but increase of the fluorescence induction. Here the maximum induction rate relative to the native ligand (100\%) is given.

\begin{tabular}{rlccc}
\hline No & Compound & Conc. & $\mathbf{C}_{12}$-AHL & $\mathbf{C}_{6}$-AHL \\
& & $\mu \mathrm{g} / \mathrm{mL}$ & $\%$ & $\%$ \\
\hline 1 & Octanoic acid & 140 & 23 & 15 \\
2 & 9-Methyl-3-decanol & 250 & 6 & -198 \\
3 & 10-Methylundecan-2-ol & 477 & 60 & 3 \\
4 & 10-Methylundecan-4-olide & 500 & 7 & -550 \\
5 & 10-Methylundec-2-en-4-olide & 432 & 59 & -40 \\
6 & 10-Methylundec-3-en-4-olide & 272 & 52 & -16 \\
7 & 10-Methyldodecan-4-olide & 535 & 71 & -70 \\
8 & 10-Methyldodec-2-en-4-olide & 175 & 61 & -32 \\
9 & 10-Methylundecan-5-olide & 312 & 82 & 15 \\
10 & 9-Methylundecan-6-olide & 35 & 20 & 12 \\
11 & 10-Methylundecan-6-olide & 37 & 26 & 41 \\
12 & 6-Ethyl-3-octanone & 250 & -15 & -39 \\
13 & 9-Methyl-3-decanone & 250 & 10 & -115 \\
14 & 9-Methyl-1-phenyldecan-1-one & 500 & 1 & -27 \\
15 & 3-Methyltridecan-4-one & 660 & 59 & -3 \\
16 & 2-Methyltridec-2-en-4-one & 517 & 52 & -9 \\
17 & 2-Methyl-4-tetradecanone & 610 & 46 & 53 \\
18 & (Z)-13-Methyltetradec-8-en-2-one & 315 & 56 & -18 \\
19 & (Z)-15-Methylhexadec-12-en-2-one & 315 & 82 & 17 \\
20 & Isopentyl formamide & 655 & 26 & 34 \\
21 & Isopentyl acetamide & 482 & 15 & 31 \\
22 & 3-Methyl- $N$-(2-phenylethyl)pentanamide & 362 & 12 & 18 \\
23 & 4-Methyl- $N$-(2-phenylethyl)pentanamide & 162 & -13 & 19 \\
\hline & & & & \\
\hline
\end{tabular}


Table 2. Cont.

\begin{tabular}{|c|c|c|c|c|}
\hline 24 & $N$-(2-phenylethyl)benzamide & 350 & 28 & 49 \\
\hline 25 & 2,5-Diisobutylpyrazine & 500 & -5 & -94 \\
\hline 26 & 2-Butyl-3,6-dimethylpyrazine & 500 & 13 & 40 \\
\hline 27 & 2-Isopropenyl-5-isopropylpyrazine & 222 & 35 & 72 \\
\hline 28 & 2-Methoxy-3,6-dimethylpyrazine & 500 & 40 & 60 \\
\hline 29 & 2-Methoxy-3,5-diisobutylpyrazine & 250 & 10 & -92 \\
\hline 30 & 2-Methoxy-3,6-diisobutylpyrazine & 500 & 26 & -102 \\
\hline 31 & 2-Methoxy-3,6-di-sec-butylpyrazine & 132 & 33 & 36 \\
\hline 32 & 2-Methylsulfanyl-3,6-dimethylpyrazine & 500 & 5 & 31 \\
\hline 33 & 4-Methylsulfanyl-2-butanol & 275 & 26 & 32 \\
\hline \multirow[t]{2}{*}{34} & S-Methyl 3-(Methylsulfanyl)propanethioate & 1375 & 54 & 85 \\
\hline & & 275 & & 40 \\
\hline 35 & $S$-Methyl benzothioate & 500 & -2 & 46 \\
\hline 36 & 2-Ethyl-5-isobutylthiophene & 250 & -25 & -180 \\
\hline 37 & 3,3,6,6-Tetramethyl-1,2,5-trithiepane & 500 & -22 & 51 \\
\hline 38 & 3,3,7,7-Tetramethyl-1,2,5-trithiepane & 500 & 25 & 18 \\
\hline 39 & 3,3,8,8-Tetramethyl-1,2,5,6-tetrathiocane & 500 & 46 & 39 \\
\hline 40 & 3,3,7,7-Tetramethyl-1,2,5,6-tetrathiocane & 250 & 30 & 20 \\
\hline 41 & 2-Pentylpyridine & 1497 & 29 & 78 \\
\hline 42 & Furfuryl isovalerate & 617 & 56 & 84 \\
\hline 43 & 2-Furylmethanol & 500 & 22 & 46 \\
\hline \multirow[t]{2}{*}{44} & Tropone & 500 & 29 & 36 \\
\hline & Common Compounds & & & \\
\hline \multirow[t]{2}{*}{45} & 3-Methylbutanol & 500 & 13 & 61 \\
\hline & & 250 & & 14 \\
\hline \multirow[t]{3}{*}{46} & 2-Phenylethanol & 500 & 45 & 69 \\
\hline & & 250 & & 23 \\
\hline & & 50 & & 31 \\
\hline 47 & $(2 R, 3 R)$-Butanediol & 500 & -14 & 7 \\
\hline 48 & Acetoin & 500 & 23 & 23 \\
\hline 49 & Geosmin & 500 & 13 & 21 \\
\hline \multirow[t]{2}{*}{50} & (+)-R-Methylisoborneol & 250 & 3 & 69 \\
\hline & & 25 & & 17 \\
\hline \multirow[t]{3}{*}{51} & (-)-S-Methylisoborneol & 500 & 12 & 75 \\
\hline & & 250 & & 24 \\
\hline & & 50 & & 10 \\
\hline 52 & Dimethyl disulfide & 500 & 17 & 26 \\
\hline
\end{tabular}

The concentration of the compounds used in the sensor tests was quite high and dilution experiments usually led to reduced activity (see Table 2). The concentration of compounds released by bacteria can be quite high close to the bacterial membrane, their point of release. Therefore, nearby other bacteria 
might well experience relatively high concentrations of such metabolites, pointing to the possibility that these compounds might have ecological relevance for known bacterial communication channels.

In summary, the results show that bacterial volatiles can, despite their relatively small size, influence different biological traits. Often it is not clear why bacteria produce volatiles. One interesting observation is that some special compounds produced by only few organisms can have antimicrobial activity and therefore might ensure survival of the bacterium when under competition with other bacteria. Contrary to polar and larger compounds they are transported by air and are useful for bacteria under certain conditions, but can also travel in water with high velocity because of their small size. The volatiles can also interfere with bacterial communication channels and are ideally suited for being signalling compounds by themselves. Their potential receptors are not known because only few bacterial communication mechanisms have been established so far (see Introduction). Finally, in some cases they may also serve as a means of detoxification, as recently proposed for some pyrazines[34]. Interestingly, the pyrazines show almost no antimicrobial activity. The activity of the volatiles against proliferative cells can be regarded as quite low with the exception of furfuryl isovalerate, a surprisingly active compound in several aspects.

Finally, there is no clear difference in activity between volatiles produced by marine or terrestrial bacteria. The current known origin of the these compounds from bacteria either of terrestrial or marine habitats is probably pure chance. Most likely terrestrial strains will be found in the future that produce compounds only known from marine sources so far, e.g., sulfur compounds 37-40, and vice versa.

In summary, we have shown that bacterial volatiles can have a multitude of activities. Their production has to be taken into account in future studies, especially when researching aspects of the bacterial chemical communication systems and their chemical defence.

\section{Experimental Section}

\subsection{Antimicrobial assay}

Antimicrobial activities were determined by agar diffusion assays using paper discs of $6 \mathrm{~mm}$ diameter soaked with $20 \mu \mathrm{L}$ of methanolic solution of the test compound. Microorganisms from the HZI collection were grown on standard media and seeded into liquid agar medium to a final O.D. of 0.01 (bacteria) or 0.1 (yeasts). Spores of fungi were seeded according to experience. Plates were incubated at $30{ }^{\circ} \mathrm{C}$ and the diameter of resulting inhibition zones were measured after 1 or 2 days.

\subsection{Cell proliferation assay}

L-929 mouse fibroblasts were obtained from the German Collection of Microorganisms and Cell Cultures (DSMZ) and cultivated at $37{ }^{\circ} \mathrm{C}$ and $10 \% \mathrm{CO}_{2}$ in DME medium (high glucose) supplemented with $10 \%$ fetal calf serum. Inhibition of proliferation was measured in microtiter plates. $60 \mu \mathrm{L}$ of serial dilutions of the test compounds were given to $120 \mu \mathrm{L}$ of the suspended cells $(50,000 / \mathrm{mL})$ in wells of 96-well plates. After 5 days growth each well was judged visually under the microscope. The lowest concentration of a compound that led to a clearly reduced growth is given as minimal inhibitory concentration (MIC). 


\subsection{Acylhomoserine lactone sensors}

The AHL biosensor strains E. coli MT102 (pJBA132) and Pseudomonas putida F117 (pRK-C12) were grown in Luria-Bertani (LB) medium with $25 \mu \mathrm{g} / \mathrm{mL}$ tetracycline at $37{ }^{\circ} \mathrm{C}$ and with $20 \mu \mathrm{g} / \mathrm{mL}$ gentamycin at $30{ }^{\circ} \mathrm{C}$, respectively. Overnight cultures $(50 \mathrm{~mL})$ of the strains were diluted with the same volume of fresh medium, incubated for about one more hour and adjusted to an OD620 of 1.0. Aliquots $(100 \mu \mathrm{L})$ of these cultures were transferred by pipet into 96-well microtiter plates which contained $90 \mu \mathrm{L}$ of LB medium, and $5 \mu \mathrm{L}$ of the test compounds in the concentrations reported in Table 2. To test the compounds for inhibitory activity on quorum-sensing, the sample wells contained $5 \mu \mathrm{L}$ of the corresponding AHL $N$-3-oxohexanoylhomoserine lactone for $E$. coli MT102, $N$-dodecanoylhomoserine lactone for P. putida F117) at a concentration of $0.25 \mu \mathrm{g} / \mathrm{mL}$. Samples containing only the corresponding AHL without test compound were used as positive control and samples containing solvent $(10 \mu \mathrm{L})$ alone were used as negative control. The microtiter plates were incubated at $30{ }^{\circ} \mathrm{C}$ with shaking. After 0,4 , 8 , and $24 \mathrm{~h}$ growth at an $\mathrm{OD}_{620 \mathrm{~nm}}$, fluorescence (excitation wavelength $485 \mathrm{~nm}$, detection wavelength of $535 \mathrm{~nm}$ ) was determined in a Victor 1420 Multilabel Counter (Perkin Elmer). Fold induction of fluorescence in the test samples was calculated by dividing their specific fluorescence (gfp535/OD620) by the specific fluorescence of the negative control. Relative activity was calculated by comparing the fold induction of positive control samples (only homoserine lactones) to samples containing samples with test compounds and the corresponding homoserine lactone.

\section{Acknowledgements}

We thank the Deutsche Forschungsgemeinschaft for financial support.

\section{References}

1. Bull, A.T.; Stach, J.E.M. Marine actinobacteria: new opportunities for natural product search and discovery. Trends Microbiol. 2007, 15, 491-499.

2. Blunt, J.W.; Copp, B.R.; Hu, W.P.; Munro, M.H.G.; Northcote, P.T.; Prinsep, M.R. Marine natural products. Nat. Prod. Rep. 2009, 26, 170-244.

3. Schulz, S.; Dickschat, J.S. Bacterial volatiles: the smell of small organisms. Nat. Prod. Rep. 2007, 24, 814-842.

4. Kai, M.; Haustein, M.; Molina, F.; Petri, A.; Scholz, B.; Piechulla, B. Bacterial volatiles and their action potential. Appl. Microbiol. Biotechnol. 2009, 81, 1001-1012.

5. Bruce, A.; Stewart, D.; Verrall, S.; Wheatley, R.E. Effect of volatiles from bacteria and yeast on the growth and pigmentation of sapstain fungi. Int. Biodeterior. Biodegradation 2003, 51, 101-108.

6. Bruce, A.; Verrall, S.; Hackett, C.A.; Wheatley, R.E. Identification of volatile organic compounds (VOCs) from bacteria and yeast causing growth inhibition of sapstain fungi. Holzforschung 2004, 58, 193-198.

7. Chaurasia, B.; Pandey, A.; Palni, L.M.S.; Trivedi, P.; Kumar, B.; Colvin, N. Diffusible and volatile compounds produced by an antagonistic Bacillus subtilis strain cause structural deformations in pathogenic fungi in vitro. Microbiol. Res. 2005, 160, 75-81. 
8. Vespermann, A.; Kai, M.; Piechulla, B. Rhizobacterial Volatiles Affect the Growth of Fungi and Arabidopsis thaliana. Appl. Environ. Microbiol. 2007, 73, 5639-5641.

9. Kai, M.; Effmert, U.; Berg, G.; Piechulla, B. Volatiles of bacterial antagonists inhibit mycelial growth of the plant pathogen Rhizoctonia solani. Arch. Mikrobiol. 2007, 187, 351-360.

10. Chuankun, X.; Minghe, M.; Leming, Z.; Keqin, Z. Soil volatile fungistasis and volatile fungistatic compounds. Soil Biol. Biochem. 2004, 36, 1997-2004.

11. Zou, C.S.; Mo, M.H.; Gu, Y.Q.; Zhou, J.P.; Zhang, K.Q. Possible contributions of volatile-producing bacteria to soil fungistasis. Soil Biol. Biochem. 2007, 39, 2371-2379.

12. Fernando, W.G.D.; Ramarathnam, R.; Krishnamoorthy, A.S.; Savchuk, S.C. Identification and use of potential bacterial organic antifungal volatiles in biocontrol. Soil Biol. Biochem. 2005, 37, 955-964.

13. Lee, J.; Jayaraman, A.; Wood, T.K. Indole is an inter-species biofilm signal mediated by SdiA. BMC Microbiol. 2007, 7, 42.

14. Mueller, R.S.; Beyhan, S.; Saini, S.G.; Yildiz, F.H.; Bartlett, D.H. Indole acts as an extracellular cue regulating gene expression in Vibrio cholerae. J. Bacteriol. 2009, 191, 3504-3516.

15. Wrigley, D.M. Inhibition of Clostridium perfringens sporulation by Bacteroides fragilis and short-chain fatty acids. Anaerobe 2004, 10, 295-300.

16. Thiel, V.; Kunze, B.; Verma, P.; Wagner-Döbler, I.; Schulz, S. New Structural Variants of Homoserine Lactones in Bacteria. Chembiochem 2009, 10, 1861-1868.

17. Blair, J.M.; Piddock, L.J. Structure, function and inhibiton of RND efflux in Gram-negative bacteria: an update. Curr. Opin. Microbiol. 2009, 12, 512-519.

18. Schulz, S.; Groenhagen, U.; Müller, R. University of Braunschweig-Institute of Technology, Braunschweig, Germany. New pyridine alkaloids in Streptomyces sp. 2010, unpublished work.

19. Dickschat, J.S.; Wenzel, S.C.; Bode, H.B.; Müller, R.; Schulz, S. Biosynthesis of volatiles by the myxobacterium Myxococcus xanthus. Chembiochem 2005, 5, 778-787.

20. Dickschat, J.S.; Bode, H.B.; Wenzel, S.C.; Müller, R.; Schulz, S. Biosynthesis and identification of volatiles released by the myxobacterium Stigmatella aurantiaca. Chembiochem 2005, 6, 2023-2033.

21. Dickschat, J.S.; Martens, T.; Brinkhoff, T.; Simon, M.; Schulz, S. Volatiles released by a Streptomyces species isolated from the North Sea. Chem. Biodivers. 2005, 2, 837-865.

22. Stritzke, K.; Schulz, S.; Laatsch, H.; Helmke, E.; Beil, W. Novel caprolactones from a marine streptomycete. J. Nat. Prod. 2004, 67, 395-401.

23. Dickschat, J.S.; Helmke, E.; Schulz, S. Volatile organic compounds from arctic bacteria of the Cytophaga-Flavobacterium-Bacteroides group: A retrobiosynthetic approach in chemotaxonomic investigations. Chem. Biodivers. 2005, 2, 318-353.

24. Böröczky, K.; Laatsch, H.; Wagner-Döbler, I.; Stritzke, K.; Schulz, S. Cluster analysis as selection and dereplication tool for the identification of new natural compounds from large sample sets. Chem. Biodivers. 2006, 3, 622-634.

25. Schulz, S.; Fuhlendorff, J.; Reichenbach, H. Identification and synthesis of volatiles released by the myxobacterium Chondromyces crocatus. Tetrahedron 2004, 60, 3863-3872. 
26. Dickschat, J.S.; Reichenbach, H.; Wagner-Döbler, I.; Schulz, S. Novel pyrazines from the myxobacterium Chondromyces crocatus and marine bacteria. Eur. J. Org. Chem. 2005, 2005, 4141-4153.

27. Dickschat, J.S.; Bode, H.B.; Kroppenstedt, R.M.; Müller, R.; Schulz, S. Biosynthesis of iso-fatty acids in myxobacteria. Org. Biomol. Chem. 2005, 3, 2824-2831.

28. Thiel, V.; Vilchez, R.; Szatjer, H.; I.Wagner-Döbler, I.; Schulz, S. Identification, Quantification, and Determination of the Absolute Configuration of the Bacterial Quorum-Sensing Signal Autoinducer-2 by Gas Chromatography-Mass Spectrometry. Chembiochem 2009, 10, 479-485.

29. Sobik, P.; Grunenberg, J.; Böröczky, K.; Laatsch, H.; Wagner-Döbler, I.; Schulz, S. Identification, synthesis, and conformation of tri- and tetrathiacycloalkanes from marine bacteria. J. Org. Chem. 2007, 72, 3776-3782.

30. Dickschat, J.S.; Nawrath, T.; Thiel, V.; Kunze, B.; Müller, R.; Schulz, S. Biosynthesis of the Off-Flavor 2-Methylisoborneol by the Myxobacterium Nannocystis exedens. Angew. Chem. Int. Ed. 2007, 46, 8287-8290.

31. Schulz, S.; Dickschat, J.S.; Müller, R. University of Braunschweig-Institute of Technology, Braunschweig, Germany. Volatile compounds from Myxobacteria. 2006, unpublished work.

32. Andersen, J.B.; Heydorn, A.; Hentzer, M.; Eberl, L.; Geisenberger, O.; Christensen, B.B.; Molin, S.; Givskov, M. gfp-Based N-Acyl Homoserine-Lactone Sensor Systems for Detection of Bacterial Communication. Appl. Environ. Microbiol. 2001, 67, 575-585.

33. Riedel, K.; Hentzer, M.; Geisenberger, O.; Huber, B.; Steidle, A.; Wu, H.; Hoiby, N.; Givskov, M.; Molin, S.; Eberl, L. N-Acylhomoserine-lactone-mediated communication between Pseudomonas aeruginosa and Burkholderia cepacia in mixed biofilms. Microbiology 2001, 147, 3249-3262.

34. Nawrath, T.; Dickschat, J.S.; Kunze, B.; Schulz, S. The Biosynthesis of Branched Dialkylpyrazines in Myxobacteria. Chem. Biodivers. 2010, 7, 2129-2144.

(C) 2010 by the authors; licensee MDPI, Basel, Switzerland. This article is an open access article distributed under the terms and conditions of the Creative Commons Attribution license (http://creativecommons.org/licenses/by/3.0/.) 